\title{
Biography as balancing act: life according to Joe and the rules of historical method
}

\section{Aroha Harris}

The papakainga (homeland, community) of the Ngati Whatua people at Okahu Bay in Auckland is a place where the people and the land are so inseparable that each defines the other. It is also a place that signifies many familiar historical patterns: of colonisation, legislation and policy-making, attitudes and perceptions that rendered Ngati Whatua politically and economically powerless, wrested them from their lands, and devastated their culture and society. These patterns recur not only throughout Aotearoa New Zealand, but also throughout the indigenous world - coloured and embellished by variations within and between tribes and cultures.

By the end of the nineteenth century, the Native Land Court had irreversibly destroyed the customary tenure and therefore tribal authority that Ngati Whatua exercised over the entire area and the colonial government had compulsorily taken the first of several sections it would eventually acquire. Then, from the early twentieth century, Auckland City openly coveted Okahu Bay. It claimed the papakainga as an area into which the city would expand, and marked out its intention by constructing a sewer line right through the front of the papakainga. By 1951, Auckland was easily New Zealand's largest and fastest growing city. It had grown up and out from what is now the Central Business District. And, in 1951, one of the gravest consequences of that growth was the forcible removal of the Ngati Whatua people from their papakainga, their home. Joseph Parata (Joe) Hawke would have been nine or ten years old at the time. His home, the home of his family, the home he was born into, was one of many deliberately burned to the ground in a government-sanctioned action that moved the people out of their traditional home and community, away from the beach and the public eye, and up the hill into state homes - that proud badge of post-war New Zealand citizenship. Twenty-six years later, Joe led whanau (family) and supporters in an occupation of Bastion Point on the ridge behind the papakainga. The occupation was a key event for the Maori land rights movement of the 1970s and 1980s. It was an attempt to stop the government of the day from selling land that Ngati Whatua asserted was rightfully theirs. That was an historical assertion, previously directed through so-called 'official' channels such as petitioning and litigation. The occupation ended spectacularly in May 1978, 507 days after it began. Police and armed forces removed the protestors 
and destroyed the temporary marae (tribal meeting house and associated land and facilities) they had erected there. ${ }^{1}$

In the aftermath, Joe, a builder by trade, found that his protest profile had rendered him unemployable. He was the subject of vicious and threatening vitriol. Ten years after the occupation the Waitangi Tribunal substantially upheld the Ngati Whatua claims to their lands, and a degree of tribal economic and community development has occurred since. Joe has been a part of those recent developments, but it is probably the younger, radical Joe, that older New Zealanders remember.

The very sketchy outline given here has cut through multiple detailed and nuanced layers to introduce Joe and his life. It also indicates some of the gristly problems that research and writing his biography presents, and into which this essay will delve. As the researcher and writer of Joe's story, by far the most gristly problems faced to date are those that attach to subjectivity - Joe's, his family's and mine. Subjectivity is arguably embedded in Maori research due to the obligations of whakapapa (genealogy, connections). Maori scholar Danny Keenan has unequivocally asserted whakapapa as the primary organising device for tribal histories. ${ }^{2}$ Few Maori historians would disagree. Charles Royal, for example, maintains that there is no such thing as Maori history, there is only tribal history. ${ }^{3}$ And Joseph Pere contends that only tribal members should be eligible to write tribal histories. ${ }^{4}$ If whakapapa, tribal belonging, is subjectivity, then these and other scholars effectively advocate subjectivity as both the analytical frame and the authority for writing Maori tribal histories. In effect, Maori scholarship embraces and even demands subjectivity, and many Maori scholars aim to do what Maori academic Linda Smith urges: to 'reprioritize and reconcile what is important about the past with what is important about the future' ${ }^{5}$

Though Maori scholarship values oral sources - the spoken accounts of life, of experience and of reality, it can and does use documentary evidence, especially the State's. But it does so critically, maybe even suspiciously, aware that the so-called official record is the record of the coloniser, of the legislator and governor who observed and wrote. Maori scholarship has also generated its own documents - some in relationship to the State and some indifferent to it - with access governed entirely by Maori protocols.

Maori scholarship has protocols that allow research participants an influential say about the projects to which they contribute. In the case of Joe's biography, that means his whanau (family) can, has and will continue to have a say about it. Before the research for Joe's biography even began, I asked Joe and a few of his family members what they wanted readers to get from reading his biography. He and his wife Rene responded quickly and clearly that the book must convey the government's progressive encroachment on Ngati Whatua territory and 
authority, the subjugation of Ngati Whatua in the name of modernity, and the mamae - the hurt - that it caused. This reflects the indivisibility of Joe's life from the land. Joe and Rene's daughter, Sharon, was also quick to respond. She said she just wanted people to see that Joe is human, a man with strengths and weaknesses. Her brother, Parata, made a similar remark, commenting on Joe as a father. Initially, this all sounded great, simple even. But it became more and more loaded with every interview, because when Joe speaks his human-ness speaks. In the inflections of his life I see and hear what I understand his children want depicted in words and images on paper. And I am struck by the enormity, difficulty and privilege of the biographer's job.

The whanau influence can easily be viewed as biased and constraining. It presents a tension that leads to the kinds of questions the 'Indigenous Lives' conference chose to address, like: who owns the story? Many more questions may be raised, cultivated by the risky admission of subjectivity into the already fraught activity of writing biography. Though I acknowledge the problems, the brevity of this essay precludes any resolution of them. Instead, it has the more modest goal of sharing a particular incident, one that demonstrates some of the difficulties faced in balancing the desires of Joe and his family with the demands of historical method.

Within the creative, academic, cultural and philosophical processes of researching and writing Joe's life is the recurring motif of the mamae, the hurt. Joe has talked about the mamae a lot. It occurs not only in his words and story-telling, but in his biting back tears; in his skirting around emotional scars that, years later, still smart; and in his conveniently finding distractions in the middle of the most poignant stories. The mamae also presents some of the project's greatest challenges, highlighting in particular the problems of subjectivity, both Joe's subjectivity and mine.

One of the earliest stories of mamae that Joe told me was from his childhood, a story about himself, his older brother Eddie and their sister, Patu. It is a story that began happily; so many children's stories do. The papakainga was the centre of Joe's childhood universe. He learned to fish, and loved to fish, from its shore. $\mathrm{He}$ ate from its gardens and orchards. He played war games and hide-and-seek in the long grass with his brothers and cousins, and though Orakei had transformed by the 1940s into a wealthy Auckland suburb, Joe's quintessentially Ngati Whatua life was largely indifferent to it.

The papakainga was joyful and rich, the social and cultural centre of its people, often filled with the music and laughter of family and relations - aunts, uncles, cousins. Joe remembers the meeting house had two pianos. Two aunties would commandeer one each and playfully compete, taking turns to play and rousing the whole house with song and dance. At the end of one of those nights, Joe, Eddie, Patu and their parents took the usual walk to their home nearby. It was 
a wonderful night, a comfortable familiar night. But it turned horribly wrong when Patu walked into a wire barb on a fence, which hooked straight into her throat. Joe and Eddie had to hold Patu still and aloft, one each side of her, while their father removed the barb careful not to let it tear. Fortunately, Patu recovered, and Joe said she has sung like a bird ever since. But she also still bears the scar tissue, as does the land, because the fence she walked into was the Crown's fence - a fence declaring the Crown's undefeatable authority over some sections within the papakainga, an authority that would eventually swallow the papakainga whole.

I cried the first time I heard this story. I cried for those three children in the past, their fortitude and their trauma. I cried for the many loaded meanings of fences and barbed wire, and their particular representation in Joe's story. And I cried for Joe in the moment he told the story. I saw him struggle with it, heard him talk over and around the mamae that came so immediately to him as he spoke. He seemed to cry without tears. I cried quiet, objective, academic tears, bowed my head so that Joe and Rene would not notice, tried to put some distance between my role as researcher-writer and my instinctive emotional response. I told myself it would be unprofessional and even unethical to cry in an interview, that it might become an intrusive distraction, and an obstacle to the freedom of Joe's expression. It is a view I stand by, the telling of life stories in research situations ought to occur openly, and not be constrained by concern for the researchers' feelings. However, my real emotions were pent up. A few minutes after leaving Joe and Rene's home that day I was overcome. I pulled over, unwittingly at the park that used to be the papakainga, and wept. I knew I had a difficult problem on my hands, one that would require me to find a way to express my human emotional responses but without impacting the interview process. I also knew it would be a problem I would face again and again as the research progressed, and this has proven to be the case as the story of Patu getting caught in the fence is but one of Joe's many stories of the mamae.

Joe's narration of the mamae brings forth the delicacies and indelicacies of his story. It makes apparent my privileged position of 'knowing' and hearing Joe as a gentlemanly grandfather, softer than his imposing frame suggests, and unfamiliar to the public's memory of Joe the radical activist. Once again I find myself in search of that happy but elusive equilibrium between telling Joe's story and 'doing' history, mining one man's past for solutions to methodological puzzles: How do I write the hard stuff? How do I academically distinguish between Joe's emotions, my emotions and the biography? How do I write over and around my own emotional responses? And on the other hand - on the Maori hand - should I? With its appreciation of subjectivity, does Maori scholarship actually seek some connection - not only to Joe in the present but also to Joe in his past? But then, if Maori scholarship calls me to embrace my personal responses, does it also call forth more problems, for instance, allegations of bias 
or of academic restraint to the detriment of academic freedom? I will not pretend I have the answers to all these questions, but I hope that laying them out allows for clarity about their existence. With the problems in the foreground, resolution of them may be able to follow later, perhaps in the simple act of completing the project effectively.

\section{Acknowledgements}

I am indebted to Nga Pae o te Maramatanga, the National Institute of Research Excellence for Maori Development and Advancement, who materially supported my attendance at the 'Indigenous Lives' conference, as well as the attendance of Joe Hawke's granddaughter, Koha Hawke, and his niece (and researcher), Tui Hawke.

\section{References}

\section{Primary sources}

Walker, RJ 1979, 'Bastion Point [papers compiled by Ranginui Walker ...]', University of Auckland General Library, Auckland.

\section{Published sources}

Hawke, Sharon 1998, Takaparawhau: The People's story, Moko Productions, Auckland.

Harris, Aroha 2008, Hikoi: Forty years of Maori protest, Huia Publications, Wellington.

Keenan, Danny 2000, in 'Ma Pango Ma Whero Ka Oti: unities and fragments in Maori history', Bronwyn Dalley and Bronwyn Labrum (eds), Fragments: New Zealand social policy and cultural history, Auckland University Press, Auckland: 44-51.

Pere, Joseph 1991, 'Hitori Maori', in The future of the past: Themes in New Zealand history, Colin Davis and Peter Lineham (eds), Department of History, Massey University, Palmerston North: 29-48.

Royal, Te Ahukaramu Charles 1992, Te Haurapa: An introduction to researching tribal histories and traditions, Bridget Williams Books, Wellington.

Smith, Linda T 1999, Decolonizing methodologies: Research and indigenous peoples, Zed Books and University of Otago Press, London and Dunedin.

Waitangi Tribunal 1987, Report of the Waitangi Tribunal on the Orakei Claim (Wai 9), Waitangi Tribunal, Wellington. 
Indigenous Biography and Autobiography

\section{ENDNOTES}

${ }^{1}$ Fuller accounts of the Bastion Point occupation and the history of the Ngati Whatua land in the area may be read in: Sharon 2008; and Waitangi Tribunal 1987. Newspaper clippings following the occupation as it unfolded throughout the late 1970s may be found in Walker 1979, 'Bastion Point [papers compiled by Ranginui Walker ...]', (available at the University of Auckland General Library).

2 Keenan 2000: 44-51.

3 Royal 1992: 9.

4 Pere 1991: 45.

${ }^{5}$ Smith 1999: 39. 